\title{
Working with Adult Learners In a Community College Setting Promoting Resilience: Using Lessons from My Teacher Education Program
}

\section{Sharon Moukperian}

A lmost one decade ago, I graduated from the teacher education program at Brock University. My motivations for entering the program were not those traditionally associated with beginning teaching. I held no desire to enter the elementary or secondary classroom, and any nurturing needs that I anticipated were satisfied by my experiences raising five children.

Indeed, if truth be known, I was rather disillusioned by my perceptions of current teaching practices and what I considered to be a lack of emphasis on the acquisition of basic literacy skills. Whether these perceptions were accurate or not is debatable, but they did serve to motivate me to enter the world of adult literacy, which has led me to my current position as the Learning Strategist at Niagara College. In this role, I have the opportunity to work with adult learners who have managed to enter a postsecondary program but face challenges with the postsecondary curriculum. They are adults considered to be "resilient" in the sense that they have navigated the primary and secondary school systems to the extent that they are now in a postsecondary program.

According to traditional definitions, resilient individuals are those who demonstrate "capacity for successful adaptation despite challenging and threatening circumstances" (Garmezy \& Masten, 1991). In other words, they are individuals who can "spring back" from adversity" (Zimmerman \& Arunkumar, 1994). Whether individuals will present themselves as resilient, is in part, dependent on the presence of protective factors including positive temperament, social competence, "healthy" family dynamics and supportive school environments (e.g., Garmezy, 1983; Rothman \& Cosden, 1995; Nichols, 2004) - the latter of which has become the focus of my career.

In 2001, following the recommendation of the Learning Opportunities Task Force chaired by Dr. Bette Stevenson (former Minister of Education), the Learning Opportunity Task Force recommended to the Ministry of Training, Colleges and Universities that enhanced services be introduced in all postsecondary educational institutions in Ontario (Nichols, Harrison, McClosky, \& Weintraub, 2002). This project was known as the Enhanced Services Fund (ESF) and its mandate was to provide academic and technological supports to postsecondary students with learning disabilities. Specifically, the program provided funding for the positions of "learning strategist" and/or "assistive technologist", with the expectation that these individuals would provide adult students with learning disabilities with the three key components that they believed were necessary for success in a postsecondary setting, including:

1. An appropriate diagnostic assessment

2. Access to personalized learning supports and accommodations provided by a learning strategist

3. Access to the services and accommodations made possible through assistive technology provided by an assistive technologist (Nichols, 2003).

In 2004, independent analysis of the Enhanced Services Funded project confirmed the importance of these positions with respect to the positive schooling experiences of adult learners (Nichols, 2004). The findings of the project also resulted in the inclusion of these positions as part of the allocated Ministry of Training, Colleges, and Universities Accessibility Funding formula, making these positions virtually permanent within each institute and opening the possibility that all individuals with learning difficulties could have access to these services.

During the implementation of the Enhanced Services Projects, postsecondary institutions increased their commitment to guaranteeing access, services, supports and accommodations for students with disabilities (Nichols, 2004). In 2005, my role as a learning strategist has expanded beyond supporting students with learning disabilities to 
being available for all students struggling academically. Currently, more students have access to strategy instruction and are more resilient because they have "learning tools" to counter their specific learning challenges.

Thus, my role as a learning strategist has become pivotal in helping adult learners: to understand their learning difficulties without a formal psycho-educational assessment, to assess their capacity to implement strategies that fit their learning style, and to apply such strategies in a manner that helps them realize their academic abilities. In my opinion, by helping these students acquire learning strategies, I am contributing to their academic and sometimes personal resilience. It is in this particular role that I utilized competencies learned during my teacher education program at Brock University, and I would like to focus on the three major ones:

\section{Constructivism:}

The adult learners I work with have constructed their own perspectives on the academic world based on experiences that have not always been positive. In this instance, my role has been to introduce strategies that help the learner to problem solve in ambiguous learning situations. I ask questions about strategies that they have used in problem solving in other life related experiences and introduce the idea of applying them in a college setting. In particular, mature students do not consider that prior experience in a nonacademic environment can be applied to completing college tasks. For example, an individual who was employed in an environment where they wrote reports would use skills such as: gathering information, verifying details, report writing, and copy editing. Similarly, the thinking skills involved for these tasks can be applied to writing a research essay. The products may be different but the thinking processes are the same.

\section{Innovative Thinking:}

During my time at Brock, my classmates and I were challenged to look at learning situations based on what materials or opportunities were available and not always by following a specific teaching script. This approach required flexibility in problem solving, good communication skills, and the ability to use creative thinking to respond to student strengths, needs, and unexpected classroom demands. Creative problem solving is a skill I used with a particular student in the $\mathrm{Ra}$ dio Broadcasting program who had a strong visual memory. This student had difficulty learning how sound waves were converted from magnetic to digital formats. In addition, her inability to remember the information triggered acute anxiety attacks. We used a combination of strategies to address these two problems: association, chaining, and visualization (Learning Strategies Database). These strategies were combined to trigger her memory for the concepts and the list of processes involved. We visualized Shania Twain singing in a recording studio and my student was the equipment operator. We developed a story that incorporated the details of the course content revolving around converting the song Shania was singing into something on tape, and then converting the taped sound to a digital format. At the same time as we recited the story, my student would draw the components and the equipment related to the conversion of the sound into different formats. The story acted as a memory cue and the visuals were associated with different parts of the story capturing all the technical information in sketches. When it came to the test, my student would tell herself the story and draw out the pictures which allowed her to remember terms and definitions. This process lead to success in passing her final exams, when she had previously failed the mid-terms.

My role is to model a strategy relevant to content material and then document

the steps so they can practice the strategy at home.

Process Oriented:

The adult students I see are very much focused on results, which lead to a great deal of anxiety around the challenges of textbook reading, essay writing, and test taking. Generally, this anxiety is based on poor academic results due to very few positive experiences with the process of learning. At Brock, Ilearned that the focus needs to be on the process of learning. It is this focus that leads to results, as students become aware of how to be successful learners. This process-oriented approach was a valuable lesson I learned which not only applies at the elementary and secondary level, but more so at the postsecondary level, as adult students with learning difficulties have more of a history of underachieving relative to their learning potential. The students I see seem unaware of how to focus on their learning strengths to achieve successful results. My role is to model a strategy relevant to content material and then document the steps so they can practice the strategy at home. As students' needs are unique the strategies are customized to work with their thought processes and unique learning styles. For instance, many first year students panic while preparing for tests. Their response is based on prior experiences of poorer performance on tests than their peers. During our time together, our goal becomes surviving the first test. The strategy is to view this first test as a learning experience, where we can do an error analysis after the test to determine areas of strength and weakness. Thus, regardless of the 
end result we have a plan to deal with success and failure on the mid-term and final exam. It is the process of preparing for this test that becomes the focus of our strategy sessions together. This process is interactive and through deconstruction of what the student did to study for the test; we construct a plan for success. We focus on what worked, where there were problems, and why certain information could not be recalled. This information allows us to develop successful strategies to apply on the next test and future exams.

\section{Concluding Remarks}

I have found it remarkable that I have been able to transfer the principles learned during my junior-intermediate teacher education program to an adult learning environment with a great deal of success. These principles have allowed me to influence students to consider, learn, apply and evaluate learning strategies, so they become independent strategy users. As the students that I see on a weekly basis experience success, their willingness to become further engaged in the learning process increases. The affective domain is a powerful motivator or inhibitor. I have found that explicit strategy instruction that is modeled and applied through a scaffold approach builds confidence, as students take ownership of the strategy and see positive academic results from applying it. These acquired learning skills and accommodations are major contributors to helping these students spring back from performing academically at a level lower than their potential.

As an educator, I enjoy watching the growth I see in my postsecondary students who have struggled throughout their elementary and secondary years. During the college years, these students start to change their perceptions about themselves as learners, because they experience academic success from applying the learning strategies that we have customized to their specific learning needs. The difference between elementary and secondary support services provided to students, and those available to students at post secondary institutions is that often, it is left to the adult learner to explore alternatives, initiate contact and follow through on strategy implementation. Learning strategies and accommodations may have been utilized in their preliminary education; however, now, the adult learner must take responsibility in applying them independently. When these students change their attitudes towards education and their perceptions of themselves as learners, I recognize the positive impact of the learning strategies they have acquired. It is then, more than ever, that I appreciate the education and training I received in the Brock Teachers Education Program, and I realize the impact the teacher educational program experience has had on my teaching abilities. I believe it is the learning opportunities I had in the program that have allowed me to be an instrument of hope for individuals who have tried to be resilient for years, in the face of academic adversity.

\section{References}

Garmezy, N. (Ed.). (1983). Stressors of childhood. Minneapolis: McGraw-Hill.

Garmezy, N. \& Masten, A. S. (1991). The protective role of competence indicators in children at risk. In E. Cummings, A.L. Greene, \& K. H. Karraker (Eds.), Lifespan developmental psychology: Per- spectives on stress and coping (pp. 151 - 174). Hillsdale, NJ: Lawrence Erlbaum Publishers.

Learning Strategies Database, $<\underline{\mathrm{http}: / /}$ fates.cns.muskingum.edu/ cal/database/general/memory5.html>

Nichols, Eva. (2003). Report on the start up and first year of implementation of enhanced services projects at all Ontario colleges and universities. Learning Opportunities Task Force. Toronto: Ministry of Training, Colleges, and Universities.

Nichols, Eva. (2004). Report on the implementation and evaluation of the pilot Enhanced Services (ESF) projects at Ontario's publicly funded colleges and universities. Toronto: Ministry of Training, Colleges, and Universities.

Nichols, E., Harrison, A., McClosky, L., \& Weintraub, L. (2002). Learning Opportunities Task Force 1997 - 2002 Final Report. Toronto: Ministry of Training, Colleges, and Universities.

Rothman, H. R., \& Cosden, M. (1995). Self-perception of a learning disability: self-concept and social support. Learning Disabilities Quarterly, 18, 203-212.

Zimmerman, M. A., \& Arunkumar, R. (1994). Resiliency research: Implications for schools and policy. Social Policy Report: Society for Research in Child Development, 8 (4), 1 - 17.

Sharon Moukperian, M.Ed., B.Ed. is the Learning Strategist for Niagara College where she provides explicit strategy instruction for students with learning and other disabilities. Sharon models

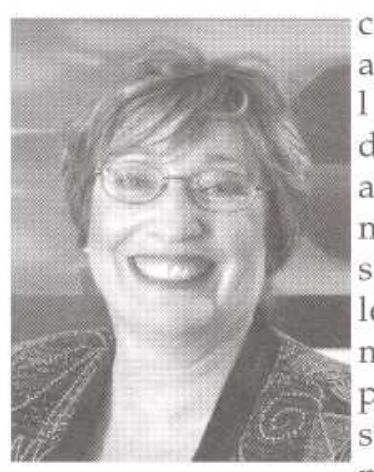
c r e a t ive approaches to l e a r n ing difficult a c a d e mic material so students can learn to maximize the power of their strengths and minimize the impact of their weaknesses. 